\title{
Evaluation of School Buildings Projects in Iraq
}

\author{
Ameer A.Alraie \\ Civil Engineering dept. \\ Faculty of Engineering, University of Kufa \\ kufa, Iraq
}

\begin{abstract}
School buildings projects in Iraq has been and continues to suffer from a significant shortfall in numbers with regard to the increase in the number of students and the incorrect method of distribution according to areas and spaces, as well as the presence of construction and design problems of those schools which obstruct its performance of functions as that there was no valid and fixed evaluation for this kind of project process.

This Paper is studying and analyzing the fact of the school projects in Iraq, all types of primary, secondary, and high schools in particular, in terms of the current and future needs and the numbers and kinds are currently available, then study and analyze design approach used for schools, the common methods of implementation, the extent to which the functional aspect of the schools and the cost and amounts of schools allocated to it through a field survey. In the study of the reality of the school buildings in the central and southern governorates of Iraq to ten governorates, there was a significant shortage of primary and secondary schools and the lack of buildings and their suffering from double and triple work and existing schools are not conforming to the specifications and held by students and the lack of safety and ventilation and lighting required and good environment has been developed treatments required to improve the school buildings in Iraq.
\end{abstract}

Keywords-Component; Formatting; Style; Styling;

\section{INTRODUCTION}

The most important problems of education in Iraq is concentrated in the lack of school buildings which suffered grievously as a result of double-shift and this suffering are summarized that the second-shift represents great effort on the student as you see a student in the first primary grade needs to attend from noon to four or five in the afternoon, no exaggeration to say that this period very difficult for an adult person where the least accommodate of human is in this period, where the studies found that the best time for study is on the period from eight in the morning to twelve noon.

one of the critical problems which hinders the success of the educational process in Iraq, the reasons for this are many, including the existence of what is called the school of a good attraction, and the lack of schools, and poorly distribution according to the urgent need, In particular, there are populated areas where students attend classes in large numbers, which may exceed 75 students per class.

Undoubtedly, It must be noted here that the problem of school buildings come in two-way, the first is concentrated in a big shortage in the number of those buildings, where the second is its age and not to keep up with scientific and cultural development, where most of these buildings in Iraq dating back to the fifties of the last century and belonged to the lacks of modern engineering designs and to the absence, as well, to the scientific, professional and sports supplements such as

\author{
Hatem Khaleefah Breesam \\ Civil Engineering dept. \\ Collage of Engineering, University of Baghdad \\ Baghdad, Iraq
}

laboratories, libraries, gymnasiums, because the classic mentality by which the schools is constructed.

Iraq needs to build nearly ten thousand schools, after it had been needed only seven thousand, with reference to the demolition of dozens of them as a result of military operations and terrorist that Iraq faced and witnessed, which making the number continues in increase. The recent security crisis exacerbated the shortage of school buildings where the crisis demolishes many of them in military operations and the displaced people fleeing from conflict zones occupy a large number of schools because they don't have shelter for them. Iraq needs to build nearly ten thousand schools, after it had been needed only seven thousand, with reference to the demolition of dozens of them as a result of military operations and terrorist that Iraq faced and witnessed, which making the number continues in increase. The recent security crisis exacerbated the shortage of school buildings where the crisis demolishes many of them in military operations and the displaced people fleeing from conflict zones occupy a large number of schools because they don't have shelter for them.

\section{RESEARCH METHODOLOGY}

Research methodology is based on the conduct theoretical and practical studies to reach the desired goals of the research in theoretical study in local studies and international studies, research and scientific publications in this field, as well as to take advantage of international network services (the Internet), The practical study is to evaluate the projects of school buildings in Iraq and identify the factors affecting the establishment of the school and the disposal of the problems it faces finally, a set of conclusions and recommendations required $t$ overcome the direct subject..

\section{RESEARCH OBJECTIVES}

The aim of the paper is to assess the projects of school buildings in Iraq and identify the factors affecting the establishment of schools and to solve the problem of the lack of construction of school buildings in Iraq through the road map to solve the problem through long-term strategic planning corresponds to the actual need for schools and the future plan and conditions in Iraq would lead to the creation of infrastructure for the educational process.

\section{RESEARCH PROBLEM}

Occupies school buildings problem is an important aspect of the educational challenges to cope with the increasing amount of students Hence the need for good planning of school buildings in the long run to take into account the growing numbers who are of school age, hence the researcher sees the need to discuss planning and evaluation of projects for the construction of school buildings in Iraq a way that meets the needs of the educational buildings in the future. 


\section{RESEARCH JUSTIFICATION}

1- the importance of school buildings as a necessary infrastructure and the great role it represents in our lives

2- The large decrease in the projects of school buildings and the failure to achieve the objectives required of them

3- School buildings require huge amounts of money and need good planning

\section{THE CONCEPT OF SCHOOL BUILDING}

The school building is considered one of the important educational elements, it represent with the curriculum and teacher, the pillars of the educational activity; so the orientation of Modern educational directs the utmost importance to the school building and its role in the success of the educational plans, and its contribution to the achievement of its objectives, and emphasizes on this important definitions, school building is defined as It constitutes a vacuum system containing a set of educational activities determined landmarks in the light of the educational philosophies adopted by the state in order to prepare the student and his education and build it physically, psychologically and value judgment, add to that, importance that comes with the design of the school building is consistent with the environment to create a framework of comfort.[1]

\section{EDUCATION SYSTEM IN IRAQ}

The stages studied by the student can be divided into kindergartens, primary and secondary education. The stage of kindergartens is one of the most important stages in an individual's life because it is a formative stage in which the person's personality is established. This stage is 3-5 years old and is not binding on children and families. Directly at the elementary without passing kindergarten.

The stage of primary education is the stage of learning to read and write and starts from the age of six at the age of the first grade and ends in the sixth grade at the age of 11 years and this stage is compulsory and prepare them for the secondary stage, which starts from the age of 12 years and ends in the sixth grade at the age of 17 years and divided into the intermediate stage starting from the first to the third and the secondary stage starts from the fourth to sixth scientific or literary and this stage is eligible for universities and institutes. There is also the Institute for the preparation of teachers and can be registered after graduating from the intermediate stage and extends for a period of 5 years and there are also professional preparation and also begins after the intermediate stage and divided into three sections of commercial, industrial and agricultural and extends the study to 3 years.[2]

\section{SCHOOL BUILDINGS PROBLEMS IN IRAQ}

1. Most school buildings are not fit for educational use, which led that the school environment losing its educational conditions to contain the student and the teacher at the same time.

2. The severe shortage of school buildings led to the lack of schools in areas where students can easily attend.

3. High-density student in schools with a high proportion of dual-shift (dual and triple), causes a negative impact on the school atmosphere..[3]

\section{LACK OF SCHOOL BUILDINGS IN IRAQ}

The Ministry of Education explained and pointed out that the country needs to build 10 thousand schools to address the problem of lack of school buildings and decoding always double and triple in a lot of areas of the country. The Minister of Education said Iraq needs to build nearly ten thousand school, after it was needed only seven thousand, pointing out that the demolition of dozens of them as a result of military operations and terrorist witnessed by the country, making the number continues to increase. Iraq was mainly suffer from a lack of school buildings, Iraqi governments did not succeed over the past ten years to decipher always double and triple in much of the country's schools and the construction needs of the buildings.[4][5]

Therefore we are in Iraq, facing several problems that relate to the school buildings, the first problem is a lack of buildings is estimated so far by more than six thousand school can be increased due to the increasing population growth, which requires the provision of more than sixty schools annually to accommodate the natural increases in population estimated at more than 3 percent annually. This means that there are more than half a million children are born each year and with the time progress, the need for more schools to be strongly present, taking into account that a lot of new residential neighborhoods don't have any school.

The second matter, is related to what are currently exists of buildings that need a very large maintenance by due to the aging of time, especially since most of them have been built in more than four decades, and this means they are no longer able to accommodate pupils and students within the geography, because they are designed in a timely manner according to estimates did not take into account the increase in the population as far as its depended on what exists at that time, and this is what made the most of Iraq's schools now busy over time whether dual, or triple.

Some may imagine that the existence of a dual or triple shift in the same school is a solution, but we have to note here that this overlap is extra special problem if it was the first shift for primary stage and second shift for other advanced stage such as an intermediate or secondary. This, certainly means that the intermediate and secondary stage will lose a lot of support in their work for foremost laboratories that would be left aside due to lack of an appropriate place. In other hand, the furniture will depreciate faster due to the dual use.[6][7]

The third problem which is considered, as well, a very important is that we are still bound by classroom system in the building of schools, including the new schools (adoption of traditional and old maps in the construction of schools), without thinking about building a school includes classrooms as we cannot study Arabic, mathematics, English and geography in one classroom and, the student requires a full year of hard work to move another classroom is never different from what it was in the last year in terms of shape and design. The best that the school be a classrooms by curriculum materials, this means that the pupil / student is going to the Hall of study on a daily lessons schedule given to him in advance, and finds in these halls, other sources to learn from them like illustration means, laboratories, and other lesson requirements and each according to its competence.

We can say that the problem is not the lack of buildings alone as much as that even if there had been such 
school buildings, they would be limited in performing its functions as an education environment because of its lack of scientific and keep pace with the significant developments in the field of education in various countries around the world. It's unable to meet the many requirements we need in the educational process because it would be unable to provide an educational environment helps students develop their skills in a practical rather than theoretical, as currently exists in our schools. [6][7].

\section{STRATEGIC PLANNING MANAGEMENT IN EDUCATIONAL BUILDINGS PROJECTS IN IRAQ}

Planning is an essential component of educational management. It is the thinking stage that precedes the implementation of any work, because strategic planning is a series of decisions related to the future to achieve the goals set.

Strategy means the effort to formulate a set of ways, alternatives or choices to achieve a set of specific objectives or objectives, so that the function of the strategy is to transform the policy into a set of decisions on the course of action and its direction for different situations that arise in the future.

Strategic planning It is the construction or structure of the plans, which includes long-term and short-term plans in various fields and levels of education. It is based on a forwardlooking perspective. It depends on the expected results of the decisions taken by the administration at a specific time. Management in the future.

The planning of the educational buildings shall take the following steps and procedures:

A. Estimating the needs of the buildings on the basis of the expected growth in the number of students, taking into account the current density of classes, and the density desired and possible during the years of the plan.

B. To limit existing buildings, to determine the extent to which they are likely to determine the need to replace them, or to maintain and repair them.

C. To determine the specifications and conditions to be met in the new buildings and to develop the relevant models.

D. Estimate the cost of the buildings to be constructed during the plan years, and propose appropriate means and methods of financing, as well as estimate the costs of maintaining or renovating the existing buildings.[8]

\section{CONDITIONS AND STANDARDS PROVIDED IN THE NEW SCHOOLS}

The Education plays an important role essential to the preparation necessary for the community to meet the actual and future needs of the country from specialists in all areas and that dictated by economic conditions, manpower, social, and cultural community and that has been happening the tremendous changes in the academic compositions, and professional as a result of scientific and technological progress and scientific revolution associated.

This requires the preparation of citizens and skilled labor as well as the preparation of specialists in the fields of academics and technicians and professionals, at all levels and specialties, and providing that characterized these programs flexibility, diversity, and keep pace with the global changes successive educational and training programs needed them.[9]

This requires the provision into education and appropriate educational (school buildings) and fit the requirements of these educational and instructional programs, in accordance with the technical standards and studied engineering specifications codified been developed based on modern educational foundations.

Existing schools and that lacked these foundations and standards, we must strive to create a new, modern schools and in accordance with the quality standards, and that our belief in the importance of the educational environment for the student in the educational attainment process, the bid amount be increased by our attention and exercise for all means of comfort for our students and our teachers.

Perhaps the most important terms and conditions of the school building is in good four main ranges which

The site, deals with site selection and the circumstances surrounding the school from the outside general features of the school building.

Educational spaces, represents a place where all are made educational activity inside the school classrooms, laboratories and training places, also include school administration, teachers, and toilet cabins.

Physical environment of the school, and represents all he environmental standards that must be taken into account when designing the school building and affecting the quality of performance within the building.

Security and safety factors, and represent all the security precautions and safety within the school environment.

One of the most general terms and specifications which must be considered when designing the school building as follows:[10][9]

- Suitable school building and vents and lighting to the nature of the environment and climate design.

- $\quad$ Provide various infrastructure such as networks (that of water for Electricity sewage)

- $\quad$ Provide public services (social services - medical cultural - sports - recreational)

- Must a building site architectural characteristics suitable in terms of simplicity and clarity of composition.

- You must take into account the aesthetics of the building that the colors of the outer surfaces are suitable as well as taking into account the areas of vision and aesthetics.

- Must fit style buildings with the nature of the educational process.

- Must fits the building site and the area of the students in the designated phase of this building.

- Must take into account the building to avoid the dangers sources (such as accidents - fires - social and moral hazard)

- Creep that is building all the various sources of pollution (such as pollution - noise - ....) and a good choice of materials and methods of construction. 
- $\quad$ The need for the building, away from water bodies to avoid moisture and general condition of the building factors

- $\quad$ Taking into account the green space which consists of trees and plants that provide shade, oxygen and form the beams to the wind.

- You must be suitable for the number of students and equipped with good furniture which allows space to move, freedom classroom.

- Appropriate classroom environment creating and ways of developing them to fall under it to provide classroom tanks special for each student, and coating the walls of the classroom bright and attractive colors and flooring good formations, easy to clean, healthy, and provide classroom board fixed ads, and a library for the season, and first aid kit, and provide a sophisticated net environment

- $\quad$ Provide a private room musical education, physical education, home economics and art education

- The availability and diversity of the private rooms of the school labs, computer labs to science labs and the labs and other languages and equipped with all the necessary accessories and furniture suitable, modern techniques of Legends, and audio-visual equipment.

- $\quad$ Provide a library of the school building, and are available where appropriate to inform wrote, while providing a good and appropriate furniture for the design of school libraries with the availability of various display modes of display screens and a projector to display the various educational, documentaries and scientific films, a special section of indexing and binding as well as the availability, and other special librarian.[11]

- Taking into account the available building a special room school radio for the exercise of cultural activity for students.

- The need to abolish the idea of school canteens current in its own way and work on the design of cafes and cafeterias modern ways and equipping with modern facilities, providing fresh meals

- Take into account pedestrian perimeter school ways.

- The need to be available for school building walls and suitable and safe entrances and are available in the design of the building all the safety rules.

- Integrity means available and adequate safety in the laboratory, school laboratories.

- The school is equipped technically, in terms of providing laboratories and equipped with the tools and materials necessary to activate Internet service on an ongoing basis, and create a site or electronic forum for each school and to link classroom management school through audio or visual network, and provide a letter for each teacher and student, and provide virtual classrooms, locking device display screen in the aisles, and contracting with technology companies to provide school kits tasked with responsibility for installation, training and maintenance.

\section{CASE STUDY OF SCHOOL BUILDINGS DIRECTORATE PROJECTS}

In order to evaluate the projects of school buildings in Iraq and to identify the reasons and factors affecting these projects, the study and analysis of these factors and problems of the school buildings were examined and the study included a survey by means of special questionnaires distributed to those working in the directorates of school buildings and educational planning of engineers, technicians, statisticians and others.

\section{DATA ACQUISITION AND COLLECTION OF INFORMATION}

Information on school buildings in the governorates of Iraq was obtained in the center and south through the following:

\section{- personal interviews}

The interviews were focused on the absence of an approved system for evaluation of school buildings and the actual need for such a system to make recommendations that would be taken to a special decision for the School buildings.

\section{- Questionnaire}

This phase included a questionnaire form distributed to a sample of civil engineers, technicians and engineers of other specialties working in the General Directorate for the education of the central and southern governorates in the school buildings of 180 form and 32 were canceled due to incomplete answers to the accepted forms 148 as shown in Table 1 below.

TABLE (1): QUESTIONNAIRE FORMS FOR SCHOOL BUILDINGS DIRECTORATE PROJECTS COVERED BY THE CASE STUDY. (RESEARCHER)

\begin{tabular}{|c|c|c|c|}
\hline No. & Directorate Name & $\begin{array}{c}\text { Number of } \\
\text { questionnaire } \\
\text { forms } \\
\text { distributed }\end{array}$ & $\begin{array}{c}\text { Number of } \\
\text { questionnaire } \\
\text { forms } \\
\text { accepted }\end{array}$ \\
\hline 1 & Baghdad & 20 & 16 \\
\hline 2 & Babel & 15 & 15 \\
\hline 3 & Al Najaf Al Ashraf & 30 & 28 \\
\hline 4 & Karbala & 16 & 16 \\
\hline 5 & Wasit & 14 & 11 \\
\hline 6 & Muthanna & 15 & 13 \\
\hline 7 & Dhi Qar & 15 & 12 \\
\hline 8 & Maysan & 15 & 17 \\
\hline 9 & Qadissixa & 20 & 9 \\
\hline 10 & Basra & 20 & 148 \\
\hline & Sum & 180 & \\
\hline
\end{tabular}

The questionnaire was built on the basis of two axes and as follows:

1. The first axis: Data and personal information The aim of the public is to know the data of the sample members, the type of sector in which they work, the specialization of the organization to which they belong, years of experience, exact specialization and job title.

2. The second axis: questions on the evaluation of school buildings aims to know the reality of the evaluation of the school buildings in the Directorate General of Education in the provinces of the center and the south, which is the basis for 
the diagnosis of problems included in the evaluation of buildings through the work of a mathematical model for school buildings.

The next step was to collect the data before entering it into the computer for the purpose of analysis. It is the coding of the data that represents the process of converting the answers to each question into numbers or characters that are easily entered into the computer, as shown in Table 2

TABLE (2): THE WEIGHT VALUES OF THE SIGNIFICANCE SCORES IN THE RESPONSES OF THE SAMPLE MEMBERS (RESEARCHER)

\begin{tabular}{|c|c|c|}
\hline No. & $\begin{array}{c}\text { Domain or } \\
\text { period }\end{array}$ & $\begin{array}{c}\text { The degree of evaluation in } \\
\text { the responses of the sample } \\
\text { members }\end{array}$ \\
\hline 1 & $0->20$ & Bad \\
\hline 2 & $20->40$ & Acceptable \\
\hline 3 & $40->60$ & Middle \\
\hline 4 & $60->80$ & Often \\
\hline 5 & $80-100$ & Always \\
\hline
\end{tabular}

XIV. STUDY POPULATION

Where the study community of engineers, technicians and experts in the implementation sites of projects and experienced in the design and implementation of school buildings projects in the directorates of education and educational planning in the provinces of the center and the south.

\section{STAGES OF THE WORK OF FIELD STUDY}

The study went through several stages to reach the most important factors affecting the construction of school buildings for the purpose of evaluation and address problems.

- $\quad$ First stage

A questionnaire form was drawn up based on the personal interviews of the engineers, the experience in the school buildings projects, the study of similar studies and previous researches, and the approach to the research topic. The researcher then made the amendments and additions and the questionnaire was finalized.

\section{- $\quad$ Second stage}

A total of 160 questionnaires were distributed to the school building directorates of the governorates, the center and the south

In Iraq, the questionnaire form consists of three parts, as described in the Annex. Part one relates to the personal information of the engineer or technician responsible for completing the form, including name, specialization, work destination, certificate, years of experience and job title.

The second part includes questions related to the projects of school buildings and their evaluation in each governorate. The third and last part are general questions for the problems that were not addressed by the researcher and observations and suggestions for improving the construction of school buildings.
Care was taken to formulate questionnaire questions using clear and easy-to-understand terms for the general respondents. Responses to the evaluation were taken into account using the options (always, often, Middle, acceptable, bad). 148 forms were correctly collected and 12 were excluded for not filling them correctly.

The researcher classified the answers in the form of data and analysis using the statistical package program (SPSS version 22).

\section{QUESTIONNAIRE AND EVALUATION QUESTIONS}

50 questions were asked for the purpose of evaluating the school buildings projects. The first 47 questions included evaluation questions by answering (always, often, Middle, acceptable, bad). The last 3 questions were general about evaluation in general and problems not addressed by the researcher, to improve the quality of the construction of school buildings. We will review the most important questions in the questionnaire and analyze their results in terms of functionality, construction, design and maintenance. The construction questions included 17 questions, functional 16, design 2, demolition, operation and maintenance 7 contracts and cost with 5 questions to be a total of 47 questions plus 3 general questions. Al Najaf-Ashraf and Baghdad Governorate for the purpose of comparison.

\section{STANDARD WEIGHTS AND PERCENTAGES OF STATISTICAL ANALYSIS}

The five Sides of the evaluation of the school buildings were identified and the main factors affecting the establishment of schools were identified for each side. These Sides are (structural, functional, design, operation, maintenance, demolition, restoration, contracting and cost). For the purpose of analyzing the results of the questionnaire, the results of Najaf and Baghdad governorates were taken and based on Equations 1, 2 and 3 as follows:

$$
\mathrm{A}=\sum_{k}^{n} \mathrm{~b} * \mathrm{c} \ldots \ldots 1
$$

$\mathrm{A}=$ Total period

$\mathrm{b}=$ Value weighted for the period

$\mathrm{c}=$ Number of answers for the period

$$
D=\frac{A}{\sum_{k}^{n} A} \ldots \ldots \ldots 2
$$

$\mathrm{D}=$ The standard weight of the coefficient within one side

$\mathrm{k}=$ The first factor in the side

$\mathrm{n}=$ The last factor in the side

$$
E=D * F * 100 \ldots \ldots 3
$$

$\mathrm{E}=$ The total standard weight of the worker within one side

$\mathrm{F}=$ The weight of one side

*** Equation 3 was multiplied by factor (100) because the degree of evaluation is 100 
First: structural Side: To illustrate the equation (1) (2) (3), the researcher applied the calculations of one factor within the constructional side as shown in the following:

\begin{tabular}{|c|c|c|c|c|c|c|c|c|}
\hline \multirow[b]{2}{*}{ Factor } & \multicolumn{5}{|c|}{ Answers of sample members } & \multirow[b]{2}{*}{ A } & \multirow[b]{2}{*}{$D * 100$} & \multirow[b]{2}{*}{$E$} \\
\hline & $\begin{array}{c}\text { Bad (B) } \\
\text { (Number*10) }\end{array}$ & $\begin{array}{c}\text { Acceptance (AC) } \\
\left.\text { (Number }{ }^{*} 30\right)\end{array}$ & $\begin{array}{l}\text { Middle (M) } \\
\text { (Number*50) }\end{array}$ & $\begin{array}{c}\text { Often }(0) \\
\text { (Number*70) }\end{array}$ & $\begin{array}{l}\text { Always (AL) } \\
\left.\text { (Number }{ }^{*} 90\right)\end{array}$ & & & \\
\hline $\begin{array}{l}\text { Availability } \\
\text { of health } \\
\text { facilities }\end{array}$ & 3 & 3 & 10 & 8 & 4 & 1540 & 6.3 & 2.23 \\
\hline
\end{tabular}

$$
\mathrm{A}=\sum_{0}^{28} \mathrm{~b} * \mathrm{c} \ldots \ldots \ldots(1)
$$

$$
\begin{aligned}
\mathrm{A}= & 3 * 10+3 * 30+10 * 50+8 * 70+4 * 90 \\
& =1540
\end{aligned}
$$

$\mathrm{n}=$ The size of the questionnaire sample for Najaf Governorate (28)

$$
\begin{aligned}
& \begin{array}{l}
\mathrm{D} \\
A / \sum_{1}^{18} A
\end{array}= \\
& \begin{array}{l}
D=1540 /(250+1080+1540+2800+1800+1040+950+1740+1200+1410 \\
\quad+1090+1780+1340+800+1660+1340+1390+1230)
\end{array} \\
& =0.063 * 100=6.3 \\
& E=D * F * 100 \ldots \ldots \ldots \text { (3) } \\
& E=0.063 * 35.5 * 100 \\
& \quad=2.23
\end{aligned}
$$

\begin{tabular}{|c|c|c|c|}
\hline No. & Sides & A & D*100 \\
\hline 1 & Structural & 24480 & 35.5 \\
\hline 2 & functional & 25970 & 37.5 \\
\hline 3 & Design & 3850 & 5.5 \\
\hline 4 & $\begin{array}{l}\text { Operation, maintenance, demolition } \\
\text { and restoration }\end{array}$ & 7970 & 11.5 \\
\hline 5 & Contracts and Cost & 6850 & 10 \\
\hline \multicolumn{2}{|r|}{ Sum } & 69120 & 100 \\
\hline
\end{tabular}

\begin{tabular}{|c|c|c|c|c|}
\hline Sintulal & hidtor & $A$ & [100 & E \\
\hline $\mathrm{M}$ & Putentuge of thy sithobs & 250 & 1.029 & 0,46 \\
\hline$x$ & 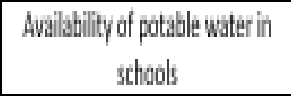 & 1010 & 4,419 & 1,86 \\
\hline 0 & 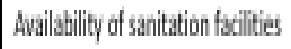 & 1540 & 6.3 & 213 \\
\hline 8 & Lighting & 200 & 11.45 & 4,16 \\
\hline $\mathrm{M}$ & Window vintilation & 180 & $7 M$ & 2.61 \\
\hline X10 & 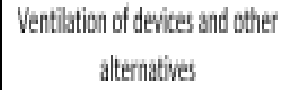 & 1040 & 4.25 & 15 \\
\hline X11 & $\begin{array}{l}\text { Staty and security in the } \\
\text { building }\end{array}$ & 90 & 38 & 137 \\
\hline$\not 1$ & 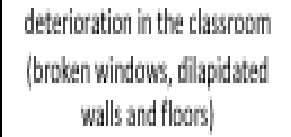 & 1740 & 7.12 & 2,9 \\
\hline 02 & 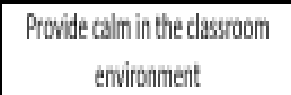 & 1200 & 4.91 & $1 . \overline{74}$ \\
\hline 04 & 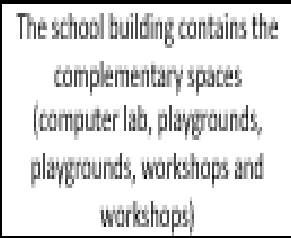 & 1410 & 577 & $2,1 / 4$ \\
\hline 26 & 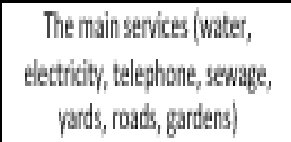 & 1090 & 4.46 & 1,98 \\
\hline xa & 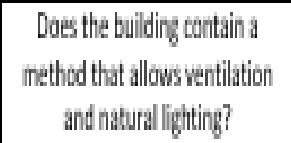 & 170 & 728 & 2,98 \\
\hline x7 & 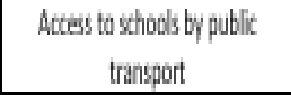 & 1340 & 5.48 & 1,94 \\
\hline b8 & 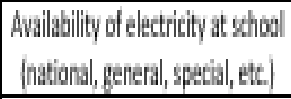 & Wo & 3.27 & 1,16 \\
\hline$x 42$ & 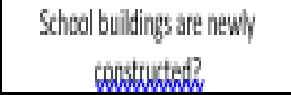 & 1660 & $6 \mathrm{~A}$ & 24 \\
\hline$x_{4}$ & 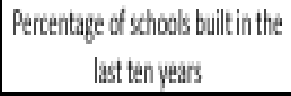 & 1340 & 5.48 & 1,94 \\
\hline$x 8$ & 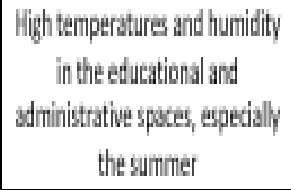 & 1390 & 5.68 & 201 \\
\hline X6t & 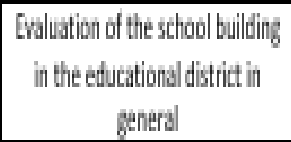 & 120 & 503 & 1.78 \\
\hline & yinh & 2440 & 100 & 35 \\
\hline
\end{tabular}

Calculate $(\mathrm{F})$ from Table 3 (the standard weight for each side) and based on equation (1) (2).

Where the results are shown in Tables $4,5,6,7$ and 8 as follows:
TABLE 4 THE TOTAL STANDARD WEIGHT OF THE FACTORS WITHIN THE STRUCTURAL SIDE

Second: Functional side: 
TABLE 5 THE TOTAL STANDARD WEIGHT OF THE FACTORS WITHIN THE FUNCTIONAL SIDE

\begin{tabular}{|c|c|c|c|c|}
\hline Symbal & factor & $\mathrm{A}$ & $D^{*} 100$ & {[} \\
\hline$x 4$ & $\begin{array}{c}\text { The lacation of the school } \\
\text { buildings shall be appropriate for } \\
\text { the purpose for which they were } \\
\text { established }\end{array}$ & 1890 & 7.3 & 2.73 \\
\hline XS & $\begin{array}{l}\text { Difficult actess to schod by } \\
\text { students }\end{array}$ & 1300 & 5.02 & 1.88 \\
\hline X11 & $\begin{array}{c}\text { The number of students per class } \\
\text { corresponds to the normal } \\
\text { number of students } \\
\text { understanding and health }\end{array}$ & 20 & 3.4 & 1.27 \\
\hline $\mathrm{X} 12$ & Near schools of residentisl aress & 1650 & 6.37 & 2.38 \\
\hline $\mathrm{X} 16$ & $\begin{array}{l}\text { School building suitable for the } \\
\text { job, which was built for it }\end{array}$ & 1830 & 7.07 & 2.65 \\
\hline$x 22$ & $\begin{array}{l}\text { The student's share of the } \\
\text { allotated space is low and the } \\
\text { students actumulate in a small } \\
\text { areas }\end{array}$ & 1600 & 6.18 & 2.31 \\
\hline$x 34$ & The school is in a hight noise area & 1280 & 4.94 & 1.85 \\
\hline X35 & $\begin{array}{l}\text { The school location allows for } \\
\text { future extension with additional } \\
\text { space }\end{array}$ & 1540 & 5.95 & 2.23 \\
\hline$\times 36$ & $\begin{array}{l}\text { The arrival of the student to } \\
\text { school an foot and without fatigue } \\
\text { especially for the first stages }\end{array}$ & 1520 & 5.87 & 2.2 \\
\hline$x 44$ & Dual attendance ratio in schools & 2100 & 8.11 & 3.04 \\
\hline X.45 & $\begin{array}{l}\text { Percentage of schools with a } \\
\text { three-time system }\end{array}$ & 860 & 3.32 & 1.24 \\
\hline$x 53$ & $\begin{array}{l}\text { Building schools in a modern } \\
\text { manner that is subject to the } \\
\text { quality aswrance system }\end{array}$ & 1100 & 4.25 & 1.59 \\
\hline X:55 & $\begin{array}{c}\text { Building schools in a modem way } \\
\text { applicable to the sustainabiilty } \\
\text { system }\end{array}$ & 1620 & 6.25 & 2.34 \\
\hline$\times 61$ & $\begin{array}{l}\text { Safety of fumiture and equipment } \\
\text { to minimize damage to buildings }\end{array}$ & 1240 & 4.79 & 1.79 \\
\hline$\times 62$ & $\begin{array}{c}\text { The quality of the appearance of } \\
\text { the school building with } \\
\text { surrounding buildings }\end{array}$ & 1240 & 4.79 & 1.79 \\
\hline$x 63$ & $\begin{array}{l}\text { The quality of the appearance of } \\
\text { the school building to suit the } \\
\text { function of the building }\end{array}$ & 1520 & 5.87 & 2.2 \\
\hline$x 64$ & $\begin{array}{c}\text { spaces to display students' } \\
\text { activities and activities }\end{array}$ & 1480 & 5.7 & 2.13 \\
\hline$\times 68$ & $\begin{array}{l}\text { Evaluation of the school building in } \\
\text { the educational district in general }\end{array}$ & 1230 & 4.75 & 1.78 \\
\hline \multicolumn{2}{|r|}{ Sum } & 25800 & 100 & 37.5 \\
\hline
\end{tabular}

Third: Design side:
TABLE 6 THE TOTAL STANDARD WEIGHT OF THE FACTORS WITHIN THE DESIGN SIDE

\begin{tabular}{|c|c|c|c|c|}
\hline Symbol & factor & A & D*100 & E \\
\hline X25 & $\begin{array}{c}\text { Is the design of the school a } \\
\text { flexible design and responsive to } \\
\text { future developments? }\end{array}$ & 1540 & 40 & 2.2 \\
\hline X60 & Lack of design flaws and errors? & 1080 & 28 & 1.54 \\
\hline X68 & $\begin{array}{c}\text { Evaluation of the school building in } \\
\text { the educational district in general }\end{array}$ & 1230 & 32 & 1.76 \\
\hline \multicolumn{2}{c}{ Sum } & 3850 & 100 & 5.5 \\
\hline
\end{tabular}

Fourth: Operation, maintenance, demolition and restoration side:

TABLE 7 THE TOTAL STANDARD WEIGHT OF THE FACTORS WITHIN THE OPERATION, MAINTENANCE, DEMOLITION AND

\begin{tabular}{|c|c|c|c|c|}
\hline Symbol & factor & A & $D^{*} 100$ & $\mathrm{E}$ \\
\hline $\mathrm{x} 2$ & $\begin{array}{l}\text { Percentage of schools demolished for } \\
\text { reconstruction }\end{array}$ & 610 & 7.77 & 0.89 \\
\hline X3 & $\begin{array}{c}\text { The size of schools that require } \\
\text { demolition }\end{array}$ & 1030 & 13.12 & 1.5 \\
\hline x17 & How much maintenance has been done & 880 & 11.2 & 1.28 \\
\hline X18 & $\begin{array}{l}\text { Type of maintenance (preventive, } \\
\text { curative, emergency) }\end{array}$ & 890 & 11.33 & 1.3 \\
\hline x49 & Percentage of schools rehabilitated & 1110 & 14.14 & 1.62 \\
\hline $\mathrm{x} 50$ & Quality of the restoration process & 1360 & 17.32 & 1.99 \\
\hline x59 & $\begin{array}{l}\text { Are high temperatures and humidity } \\
\text { treated? }\end{array}$ & 740 & 9.42 & 1.08 \\
\hline x68 & $\begin{array}{l}\text { Evaluation of the school building in the } \\
\text { educational district in general }\end{array}$ & 1230 & 15.66 & 1.8 \\
\hline & Sum & 7850 & 100 & 11.5 \\
\hline
\end{tabular}

Fifth: Contracts and Cost side:

TABLE 8 THE TOTAL STANDARD WEIGHT OF THE FACTORS WITHIN THE CONTRACTS AND COSTSIDE

\begin{tabular}{|c|c|c|c|c|}
\hline Symbol & factor & A & D*100 & E \\
\hline X46 & $\begin{array}{c}\text { Provide financial allocation (ministry, } \\
\text { governorate, other sources) }\end{array}$ & 480 & 7.63 & 0.76 \\
\hline X51 & $\begin{array}{c}\text { Is there a trend towards the private } \\
\text { sector and investment companies to } \\
\text { build schools? }\end{array}$ & 760 & 12.08 & 1.208 \\
\hline X52 & $\begin{array}{c}\text { Feasibility of the private sector in } \\
\text { construction }\end{array}$ & 1080 & 17.17 & 1.717 \\
\hline X57 & $\begin{array}{c}\text { The existence of a plan for future } \\
\text { projects to build schools and fill the } \\
\text { shortfall and deficit }\end{array}$ & 1160 & 18.44 & 1.844 \\
\hline X65 & $\begin{array}{c}\text { Type of companies contracted to build } \\
\text { schools (local, government, foreign) }\end{array}$ & 1580 & 25.11 & 2.511 \\
\hline X68 & $\begin{array}{c}\text { Evaluation of the school building in the } \\
\text { educational district in general }\end{array}$ & 1230 & 19.55 & 1.955 \\
\hline & Sum & 6290 & 100 & 10 \\
\hline
\end{tabular}




\section{DISCUSS THE RESULTS}

The analysis of the data for the provinces of Baghdad and Najaf and finding the standard weights and percentages of each of the five aspects, we find that the ratios were close, indicating that the results taken from different samples are almost the same so we suggest that the weight of the structural aspect is $35 \%$, functional $37 \%$, design $5 \%$, operation, maintenance, restoration $12 \%$, contracts, cost $11 \%$.

The weights of the weights and factors $X$ are shown in Table 9 as follows:

TABLE 9 FINAL PERCENTAGES OF WEIGHTS AND X FACTORS

\begin{tabular}{|c|c|c|c|c|c|c|c|c|c|}
\hline Factor & $\times 23$ & X21 & X13 & $\times 10$ & X9 & X8 & $x_{7}$ & $x_{6}$ & $x_{1}$ \\
\hline percentage \% & 2 & 2.5 & 1.2 & 1 & 2.7 & 3.5 & 2.2 & 2 & 0.4 \\
\hline Factor & X68 & X58 & X43 & X42 & X38 & $\times 37$ & X33 & $x 26$ & X24 \\
\hline percentage \% & 1.5 & 2.5 & 1.5 & 2 & 1.5 & 2 & 2.5 & 2 & 2 \\
\hline Factor & X36 & X35 & X34 & $\times 22$ & $\times 16$ & X12 & X11 & $\times 5$ & X4 \\
\hline percentage \% & 2.4 & 2.3 & 2 & 2.2 & 2.8 & 2.7 & 1.2 & 2 & 2.5 \\
\hline Factor & X68 & X64 & X63 & X62 & X61 & X55 & X53 & X45 & X44 \\
\hline percentage \% & 1.5 & 2.2 & 2.2 & 2 & 2 & 2.2 & 1.7 & 1.2 & 2.8 \\
\hline Factor & X50 & X49 & $\times 18$ & X17 & $x 3$ & $\times 2$ & $\times 68$ & $\times 60$ & $\times 25$ \\
\hline percentage \% & 1.9 & 1.8 & 1.4 & 1.5 & 1.6 & 1 & 1.5 & 1.8 & 1.6 \\
\hline Factor & & X68 & X65 & X57 & $\times 52$ & X51 & X46 & X68 & X59 \\
\hline percentage \% & & 1.5 & 3 & 2 & 2 & 1 & 1 & 1.5 & 1 \\
\hline
\end{tabular}

XIX. VALIDITY AND RELIABILITY TEST

The validity and reliability of the questionnaire used in data collection using the (Cronbach's Alpha coefficient) was performed according to the equation:

$$
\alpha=\frac{k}{k-1}\left[1-\frac{\sum s_{i}^{2}}{s_{i}^{2}}\right]
$$

$\alpha$ : Cronbach's alpha coefficient.

$\mathrm{K}$ : number of elements in-group.

Si: element of variance.

St: the variance of total score of the elements

And (Pearson Correlation Coefficient) to measure the degree of correlation and to find out whether the field survey matches the questionnaire using the following equation

$$
r=\frac{n \sum x y-\left(\sum x\right)\left(\sum y\right)}{\sqrt{n\left(\sum x^{2}\right)-\left(\sum x\right)^{2}} \sqrt{n\left(\sum y^{2}\right)-\left(\sum y\right)^{2}}}
$$

If the value of the alpha coefficient is close to one which is high, this indicates the stability of the questionnaire, noting that the coefficient of stability between (0-1) The coefficient of (Cronbach's Alpha) was 0.971 for $\mathrm{N}$ of 69 and the number of forms 148 was high and close to one of the Indicates the availability of a high degree of stability of the questionnaire in addition to its validity, urging that the coefficient of Cronbach's coefficient should not be less than
0.75. The data were tested and whether they were normal distribution using SPSS V.22 and hypothesis testing for samples greater than 50 and the results for the Significance level were greater than 0.05 , indicating that the distribution data was normal.

(Correlation Coefficient) was calculated to determine the coefficient of linear correlation, the strength of the correlation and the degree of relationship between the variables using the (Pearson Correlation coefficient) because the distribution data is normal and the sample size is greater than 30. levels of significance (Sig) for all variables and the value of $r$ shows the existence of a positive correlation between the extrusive variables, which indicates how closely the results of field survey with a questionnaire that supports the validity of the results.

\section{CONCLUSIONS}

1. The reasons for the stoppage of school buildings projects is the lack of financial allocation in the 2016 and 2017 years that allocated for establishment and rehabilitation of school buildings, which led to delay of companies and the withdrawal of work or the dissolution of the contract.

2. The absence of a studied plan for school buildings.

3. Engineering designs for schools don't fit the environment and the current situation in terms of (lack of electricity the lack of modern cooling systems). In addition to Lack of healthy ventilation, good lighting and the environment for learning.

4. Frequent change orders in contracts of the construction of school buildings.

5. Lack of schools and lack of proportion to the number of students and population growth.

6. The bad work of companies because they don't have sufficient experience.

7. The absence of plots dedicated to the establishment of schools, which led to rely on the old existing buildings.

8. The system of referral to lowest tender is ineffective and the lack of monitoring authorities and controls, which makes the occurrence of problems led to the failure to establish the schools with specifications required. As well, the number of engineering staff does not match with the needed supervision of schools construction projects.

9. Most projects are out of work, with more than 750 to 800 projects being discontinued, including schools, owing to the absence of allocations in the 2016 and 2017 budgets. That led to Withdrawal of most of the projects for school buildings due to delay of contractors.

\section{RECOMMENDATIONS}

1. Training of staff, engineers and technicians to avoid problems in the implementation of school buildings.

2. Adoption of modern designs suitable to the nature of the areas where the schools are located, in most of the schools that were created with a single design has not changed for a long time to become the capacity to accommodate as many students as possible to remove duplication and address overcrowding in schools. 
3. Providing financial liquidity for the purpose of establishing the largest number of schools due to the high shortage of school buildings.

4. Provide the adequate number of civil engineers to follow up and supervise due to the lack of them in the school buildings department.

5. The need for foreign companies for the implementation of school buildings and the use of new means.

6. Study the real numbers of students and the establishment of additional supplements without the need to stifle the building or overrun on the playgrounds.

7. Use multi-storey construction to meet the shortage of land allocated to school buildings, especially in the city center.

8. Concerted efforts between the government and the citizens, where the responsibility of the government to provide and establish and maintain schools, and making awareness campaigns using the television and social media to motivate the citizens to urge their children to maintain the school building.

\section{REFERENCES}

[1] Fahad Bin Sulaiman Bin Ibrahim, 2008, "Criteria for Selecting School Buildings Sites in the Kingdom of Saudi Arabia (Case Study - Qassim Region), Master Thesis, Department of Architecture and Building Sciences, College of Architecture and Planning, King Saud University.

[2] Aziz, Zine El Abidine 2012, "spatial analysis of educational services (kindergartens and schools) in the city of Najaf using the GIS technology", Master Thesis, University of Kufa, Faculty of Arts Department of Geography.

[3] Basima Alwan Hussein, M. Fouad Thomas, 2009, "The Evolution of Education in Iraq", Directorate General of Educational Planning, Educational Studies, No. 6.

[4] Al-Hamdani, Hussein Ali 2013, "Education in Iraq - Problems and Solutions", Studies, Biratha News Agency.

[5] UNESCO, United Nations, 2013, "Strategies for teacher development and professional development", Office of Iraq.

[6] Jarad, Mohamed Sadiq 2013, "The Crisis of School Buildings" Al-Mada Newspaper, Opinions and Ideas, No. (2938).

[7] Waseem Basim, 2016, "Education in Iraq - A Serious Shortage in School Buildings", Pulse Iraq.

[8] Ghanoum, Ahmed bin Abdul Karim 2009, "The role of strategic planning in higher education institutions", presented at the seminar (Strategic Management in Higher Education Institutions).

[9] Al-Zuaybar, Ibrahim bin Abdullah bin Abdul Rahman, Khuloud Al Masood, 2009, "The School Environment in the Axes of Comprehensive Assessment", electronic version of Riyadh newspaper, Issue 14831.

[10] Al Shibli, Fathia Salem Mokhtar 2012, "Specifications of a Good School Building", a research paper presented at the First National Education Forum.

[11] Bajhazer, Khalid Saleh 2013, "Problem of School Buildings in Public Education" Procedural Research 